\title{
Comparative Advantage in Indian Economy: 1990-2014
}

\author{
Gholamreza Fathipour*1, Pratibha S. Gaikwad ${ }^{2}$ \\ ${ }^{1}$ Budget and planning organizaton of Hamedan, Iran \\ ${ }^{2}$ D.G. College Satara, Shivaji University Kolhapur, India \\ *sasansara50@gmail.com, pratibhasg11@gmail.com
}

\begin{abstract}
The most countries try to improve their advantage towards goods with high range of demand and sustainable trade such as industrial goods and merchandise. India embarked on the path of globalization in the early 1990s with the objective to attain a higher growth profile. This question can be brought up in which goods India has have comparative adventage. The aim of this study is to analyze comparative advantages of Indian's exports commodities during of post liberalsation in 1990-2014. The well-known index for determining trade advantage is revealed comparative advantage (RCA) by Balasa. The findings by India's RCA in exports showed India has gained comparative advantage in a number of agriculture sector such as Food items, Textiles, Leather and other Manufactures.
\end{abstract}

\section{Keywords: Comparative advantage index, Trade relation, agricultural and industrial goods}

\section{Introduction}

The concept of Revealed Comparative Advantage (RCA) has been developed by Balasa (1965) for improving Ricardo theory who had laid down the basic tenets of comparative advantage. The term can note that countries specialize and export items, which they can produce at lower cost in comparison to the world. In Balasa's (1985) view, the comparative advantage that a country enjoys primarily depends on its physical and human capital endowments (Burange, 2008). India embarked on the path of globalization in the early 1990s with the objective of improving overall productivity, competitiveness and efficiency of the economy in order to attain a higher growth profile. India is a newly industrialized country; it has a long history of collaboration with several countries and is considered one of the leaders of the developing world along with China, Brazil, Russia and South Africa. India was one of the founding members of several international organizations, most notably the United Nations, the Asian Development Bank, G20industrial nations and the founder of the Nonaligned movement. India has also played an important and influential role in other international organizations like East Asia Summit, World Trade Organization, International Monetary Fund (IMF), G8+5 and IBSA Dialogue Forum. Regionally, India is a part of South Asian Association for Regional Cooperation (SAARC). India has taken part in several UN peacekeeping missions and in 2007; it was the second-largest troop contributor to the United Nations. India has made an extensive effort to liberalize its international trade since 1991 and the consequent increase in competitive pressures and technology transfers, is expected to have led to a restructuring of the economy such that the composition of exports reflects India's comparative advantage in the global economy. Therefore, it is important to explore the structure of comparative advantage of India and the extent to which the economic sectors can compete with others in the global market for manufacturing sector commodities. With Considering of economic data and information this question can be brought up that India in which commodities has comparative advantage. In the next section, for answering to this question, the Indian export comparative advantage will be computed. Therefore, the rest of the paper is organized as follows. Sections two will review composition of India's foreign trade and direction of India's foreign trade. Competitive advantage concept and determination methods are provided in section three and followed by the summary and conclusion in the last section.

\section{Composition of India's foreign trade}

Generally, a clear trend over the years exposes a decline in the importance of agriculture and allied products and a substantial increase in the importance of manufactured products. For instance, the share of Agriculture and Allied products in total exports fell considerably from $44.2 \%$ in 1960-61 to $21.1 \%$ in 1996-97 while the share of manufactured products increased from $45.3 \%$ to $74.5 \%$ over the same period (Misra and Puri, 1998). However, recently the share of Agriculture and Allied products reduced from $14.19 \%$ accounting for US\$ 6256 $\mathrm{mn}$ in $2000-2001$ to $9.7 \%$ accounting for US\$ $24448 \mathrm{mn}$ in $2010-11$ and finally increased from $9.7 \%$ to $12.34 \%$ accounting for US $\$ 37618 \mathrm{mn}$ in 2011-12 while that of manufactured products reduced considerably 
and continuously from $79.81 \%$ accounting for US\$ $35181 \mathrm{mn}$ to $69 \%$ accounting for US\$ $173263 \mathrm{mn}$ and thus culminating to $66 \%$ accounting for US\$201237 mn respectively, over the same periods. Likewise, the other two items of India's exports have undergone so much of changes. For example, the share of Ores and Minerals (excluding Coal) in total exports increased slightly from $2.05 \%$ in 2000-01 to 3.4\% in 2010-11 and then it reduced from $3.4 \%$ to $2.8 \%$ in 2011-12 while the share of Mineral fuels and lubricants (including Coal) increased significantly from $4.38 \%$ in $2000-01$ to $16.8 \%$ in $2010-11$ and therefore to $18.71 \%$ in $2011-12$. The top exports of India are Refined Petroleum ( $\$ 29.2$ B), Diamonds ( $\$ 23.2$ B), Packaged Medicaments ( $\$ 13.4$ B), Jewellery ( $\$ 9.2$ B) and Rice ( $\$ 6.55$ B), using the 1992 revision of the HS (Harmonized System) classification. Its top imports are Crude Petroleum ( $\$ 64.6$ B), Gold (\$35.4 B), Diamonds ( $\$ 17.2$ B), Coal Briquettes ( $\$ 13.9$ B) and Petroleum Gas $(\$ 11.7$ B). The top export destinations of India are the United States ( $\$ 44.1$ B), the United Arab Emirates ( $\$ 30$ B), China ( $\$ 12$ B), Hong Kong ( $\$ 11.4$ B) and the United Kingdom ( $\$ 9.2 \mathrm{~B})$. The top import origins are China $(\$ 59 \mathrm{~B})$, Switzerland $(\$ 21.5 \mathrm{~B})$, the United States $(\$ 20$ B), Saudi Arabia (\$19.9 B) and the United Arab Emirates (\$19.4B) (Workman, 2017). In 2015 India exported $\$ 276 \mathrm{~B}$, making it the 16th largest exporter in the world. During the last five years the exports of India have increased at an annualized rate of $2.9 \%$, from $\$ 205 \mathrm{~B}$ in 2010 to $\$ 276 \mathrm{~B}$ in 2015 . The most recent exports are led by Refined Petroleum which represent $10.6 \%$ of the total exports of India, followed by Diamonds, which account for $8.4 \%$.

Table 1: Value and percentage share of Major items of Indian's exports 1990-2014

\begin{tabular}{|c|c|c|c|c|c|c|c|c|}
\hline \multirow[b]{2}{*}{ Commodity Group } & \multicolumn{2}{|l|}{$1990-91$} & \multicolumn{2}{|l|}{$2000-01$} & \multicolumn{2}{|l|}{$2010-11$} & \multicolumn{2}{|c|}{ 2014-2015 } \\
\hline & $\begin{array}{l}\$ \\
\text { million }\end{array}$ & $\begin{array}{l}\text { share } \\
\%\end{array}$ & $\begin{array}{l}\$ \\
\text { million }\end{array}$ & $\begin{array}{l}\text { share } \\
\%\end{array}$ & $\begin{array}{l}\$ \\
\text { million }\end{array}$ & $\begin{array}{l}\text { share } \\
\%\end{array}$ & $\begin{array}{l}\text { \$ } \\
\text { million }\end{array}$ & $\begin{array}{l}\text { share } \\
\%\end{array}$ \\
\hline Agricultural and allied products & 3521 & 19.41 & 6256 & 14.19 & 24448 & 9.73 & 39357 & 12.69 \\
\hline Ores and minerals (excl. coal) & 834 & 4.60 & 906 & 2.06 & 8581 & 3.42 & 4680 & 1.51 \\
\hline Manufactured goods & 13229 & 72.92 & 35181 & 79.82 & 173263 & 68.99 & 207087 & 66.77 \\
\hline $\begin{array}{l}\text { Mineral fuels and lubricants (incl. } \\
\text { coal) }\end{array}$ & 528 & 2.91 & 1931 & 4.38 & 42280 & 16.84 & 57405 & 18.51 \\
\hline Total export & 18143 & 100.00 & 44076 & 100.00 & 251136 & 100.00 & 310147 & 101.00 \\
\hline
\end{tabular}

Source: Economic Survey (Statistical Appendix) and researchers' calculation

Table 2: Value and percentage share of principal items of Indian's imports 1990-2014

\begin{tabular}{|c|c|c|c|c|c|c|c|c|}
\hline & 1990-91 & & 2000-01 & & 2010-11 & & 2014-15 & \\
\hline Commodity Group & \$ million & $\begin{array}{l}\text { share } \\
\%\end{array}$ & $\begin{array}{l}\$ \\
\text { million }\end{array}$ & $\begin{array}{l}\text { share } \\
\%\end{array}$ & $\begin{array}{l}\$ \\
\text { million }\end{array}$ & $\begin{array}{l}\text { share } \\
\%\end{array}$ & $\begin{array}{l}\$ \\
\text { million }\end{array}$ & $\begin{array}{l}\text { share } \\
\%\end{array}$ \\
\hline II.4 Petroleum, oil and lubricants & 6028 & 25.04 & 15650 & 30.44 & 105964 & 28.66 & 138326 & 30.87 \\
\hline II.5.1 Edible oils & 182 & 0.76 & 1334 & 2.59 & 6551 & 1.77 & 10621 & 2.37 \\
\hline II.6.1 Fertilizers and fertilizer $\mathrm{mfg}$ & 984 & 4.09 & 664 & 1.29 & 6885 & 1.86 & 7399 & 1.65 \\
\hline II.6.2 Chemical elements and compounds & 1276 & 5.30 & 338 & 0.66 & 2914 & 0.79 & 23899 & 5.33 \\
\hline $\begin{array}{l}\text { II.6.5 Plastic material, regenerated cellulose and } \\
\text { artificial resins }\end{array}$ & 610 & 2.53 & 558 & 1.09 & 6874 & 1.86 & 10943 & 2.44 \\
\hline $\begin{array}{l}\text { II.9.1 Pearls, precious and semiprecious stones, } \\
\text { unworked or worked }\end{array}$ & 2083 & 8.65 & 4838 & 9.41 & 346 & 9.36 & 22598 & 5.04 \\
\hline II.10 Iron and steel & 1178 & 4.89 & 781 & 1.52 & 10376 & 2.81 & 16301 & 3.64 \\
\hline II.11 Non-ferrous metals & 614 & 2.55 & 539 & 1.05 & 4667 & 1.26 & 49676 & 11.09 \\
\hline III. Capital goodsa & 5833 & 24.23 & 5534 & 10.76 & 50907 & 13.77 & 53298 & 11.90 \\
\hline $\begin{array}{l}\text { III.2 Non-electrical machineryb apparatus and } \\
\text { appliances including machine tools }\end{array}$ & 2363 & 9.82 & 3703 & 7.20 & 26111 & 7.06 & $\ldots$ & $\ldots$ \\
\hline III.3 Electrical machineries, apparatus and appliancesb & 949 & 3.94 & 487 & 0.95 & 3845 & 1.04 & & $\cdots$ \\
\hline III.4 Transport equipmen Total Import & 931 & $\begin{array}{l}3.87 \\
100.0\end{array}$ & 953 & $\begin{array}{l}1.85 \\
100.0\end{array}$ & 11467 & $\begin{array}{l}3.10 \\
100.0\end{array}$ & $\ldots$. & $\cdots$ \\
\hline Total import & 24075 & 0 & 51413 & 0 & 369769 & 0 & 448033 & 0 \\
\hline
\end{tabular}

Source: Economic Survey (Statistical Appendix) and researchers' calculation

With the initiation of the planning process in India in 1951-52, and more specifically with the beginning of Second Five Year plan in 1956-57, composition of India's import underwent a considerable change. It imposed a heavy emphasis on the development of capital goods and basic industries. As a result, it became necessary to import capital equipment in large quantities. The importable items of India have divided into 
four broad groups: A) Food and live animals chiefly for food B) Raw materials and intermediate manufactures C) Capital goods D) Other goods. From the second group, Raw materials and intermediate manufactures, the item Petroleum oil and lubricants and Iron and steel have been playing a vital role in the total imports in comparison to Fertilizers and Chemical elements and compounds. In this way, the total share of import of Petroleum oil and lubricants declined from $31.31 \%$ accounting for US\$ $15650 \mathrm{mn}$ in 2000-01 to 28.65\% accounting for US\$ $105964 \mathrm{mn}$ in $2010-11$ and finally, it increased from $28.65 \%$ to $31.66 \%$ accounting for US\$ $154906 \mathrm{mn}$ in 2011-12 while that of Iron and steel increased from 1.56\% accounting for US\$ $781 \mathrm{mn}$ in 2000-01 to $2.8 \%$ accounting for US\$ $10376 \mathrm{mn}$ in $2010-11$ and suddenly the share of $2.8 \%$ fell down to $2.4 \%$ accounting for US\$ $11959 \mathrm{mn}$ in 2011-12.

However, the total share of two other items increased continuously due to a constant rise in the share of Fertilizers in such way that their total share augmented from $1.99 \%$ in 2000-01 to $2.58 \%$ in 2010-11 and at last to $2.94 \%$ in 2011-12. The following product groups represent the highest dollar value in India's import purchases during 2016 also is shown the percentage share each product category represents in terms of overall imports into India. Mineral fuels including oil: US $\$ 89.3$ billion (25\% of total imports) ; Gems, precious metals: $\$ 48.1$ billion (13.5\%) ; Electrical machinery, equipment: $\$ 37$ billion $(10.4 \%)$; Machinery including computers: $\$ 32.5$ billion (9.1\%) ; Organic chemicals: $\$ 14.8$ billion (4.1\%) ; Plastics, plastic articles: $\$ 11.4$ billion (3.2\%) ; Animal/vegetable fats, oils, waxes: $\$ 10.5$ billion (2.9\%) ; Iron, steel: $\$ 8.7$ billion (2.4\%) ; Optical, technical, medical apparatus: $\$ 7.2$ billion $(2 \%)$; Ships, boats: $\$ 5.5$ billion $(1.5 \%)$ and Imported plastics and plastic articles had the fastest-growing increase in value among the top 10 import categories, up $121.9 \%$ for the 7 -year period starting in 2009. In 2015 India imported $\$ 368 \mathrm{~B}$, making it the 14th largest importer in the world. During the last five years the imports of India have increased at an annualized rate of $1.1 \%$, from $\$ 324 \mathrm{~B}$ in 2010 to $\$ 368 \mathrm{~B}$ in 2015 . The most recent imports are led by Crude Petroleum which represent $17.5 \%$ of the total imports of India, followed by Gold, which account for $9.6 \%$. (Workman ,2017)

\section{Competitive advantage}

Comparative advantage which is raised in relation to international trade means if a country manufacture and export a good cheaper than other goods, that country has comparative advantage in production of such goods, therefore upon entering into world experiences scene, we may benefit from export of goods providing comparative advantage. Since emerging the concept or principle of comparative advantage, its concept has been varied intensively. Ricardo defined the comparative advantage based on the actual value of work consumed for good production. According to the theory of Ricardo, comparative advantage means a country manufactures a good with lower actual work than the other goods. Even if production of a country's goods is running with higher work than the other countries, comparative advantage or superiority of this country for production and trade is allocated to goods with the minimum absolute non-advantage. Gradually, the concept of Ricardo's comparative advantage based on actual value of work was replaced by theory of "comparative advantage of missed opportunities cost". Nevertheless, the above theories follow a goal means expression of countries' exchange cause. With respect to basis, the concept of regional advantage is mostly similar to the presented international definitions, with this difference that in the regions, production factor is focused. According to comparative advantage principle, each region intends to be allocated for production and export of goods with lower costs; in other word, each region comparing to other regions or manufacturing goods have tendency to manufacture the goods that obtain more advantage or lower non-advantage for their production. This concept has been known as comparative advantage principle. In general, comparative advantage may be defined as capability of a country in production and export of goods with cheaper cost and higher quality (Stiglitz, 2002).

The commodity pattern of comparative advantage is a central concept in international trade theory. However, the empirical measurement of comparative advantage is difficult because the concept is defined in terms of relative autarkic prices, which are not observable in post-trade equilibrium. To compute the competitive advantage, various methods and indices have been used. Some of them are completely formed based on theoretical and unreal factors such as competitive performance of markets, and their results are lowly reliable, hence economists focus on the statistics and data after foreign trade exchanges and determine the competitive advantage based on these data. One of indices used inspiring of a country's export statistics for computation of competitive advantage and known as functional method (Lee, 1995). Datt and Sundharam 
(2010) analyzed different properties of RCA indices to estimate the actual competitive advantage. Vollrath (1991) is one of economists that applied studies on measurement of competitive advantage and ultimately introduced the completed index of Balasa as follows:

$$
\begin{aligned}
& R C A_{a}^{i}=\left[\frac{X_{a}^{i}}{X_{t}^{i}}\right],\left[\frac{X_{a}^{w}}{X_{t}^{w}}\right] \\
& X_{a}^{i}: \text { Export value of manufacturing or nonmanufacturing good a of country i } \\
& X_{t}^{i}: \text { Export value of export goods of country i } \\
& X_{a}^{w}: \text { Total exporting value of goods a in the world } \\
& X_{a}^{i}: \text { Export value of all exporting goods in the world }
\end{aligned}
$$

The numerator represents the percentage share of a given sector (or product) in national exports Xij is exports of sector (or product) i from country j. The denominator represents the percentage share of a given sector (or product) in total world exports. The RCA index, thus, contains a comparison of national export structure (the numerator) with the world export structure (the denominator). When RCA equals 1 for a given sector (or product) in a given country, the percentage share of that sector (or product) is identical with the world average. Where RCA is above 1 the country is said to have a comparative advantage (and specialized) in that sector (or product) and vice versa where RCA is below 1. Batra \& Zeba (2005), in the study titeld "Revealed comparative adventageand analysis for India and China" The paper identified the pattern of revealed comparative advantage using the Balasa (1965) index for export data. The index has been calculated at the sector and commodity level of the Harmonized System of classification. The paper also analyses comparative advantage according to factor intensity. The analysis has showed broad similarities in the structure of comparative advantage for India and China. Both, India and China enjoy comparative advantage for labour and resource intensive sectors in the global market.

Shinoj \& Mathur (2008) in their study entitled "Comparative Advantage of India in Agricultural Exports vis-ávis Asia: A Post-Reforms Analysis "has examined the changes in comparative advantage status of India's major agricultural exports with other Asian countries during in the period 1991-2004. They found India has been found losing out its comparative advantage in export of some of the agricultural commodities to other Asian competitors during the period after economic reforms. Therefore, in exports of certain commodities like cashew and oil meals, India has been able to maintain its comparative advantage, but several others like tea, coffee, spices, marine products, etc. have been negatively affected. Burange (2008) in their paper entitled " India's Revealed Comparative Advantage in Merchandise Trade", has assessed India's revealed comparative advantage (RCA) in merchandise trade. The study evaluated the structure of comparative advantage in India and the change in the scene over a 10-year period from 1996 to 2005. The paper has also evaluated India's RCA in exports and imports in different type of goods categorized on the basis of their production. As per the HS classification, India has enjoyied comparative advantage in the exports of labour-intensive items like textiles and scale-intensive items such as chemicals and iron and steel. Results suggest that India enjoys a comparative advantage in the exports of Ricardo and HO goods. PC goods in contrast have not displayed any improvement in the RCA universe. On the import front, it is essentially Ricardo goods where India enjoys comparative advantage. All production of goods requiring standard technology is shifting to developing economies like India as reflected in the absence of RCA in imports of HO goods (Sinate et al., 2012).

Fathipour \& Ghahremanlou (2014), in the study titled " Economical-Regional Integration - An Overview on Iran-India Trade Relation" has stated that India and Iran trade relations were based on the comparative advantages of different economic capabilities and due to this principle an escalating prosperity and an increasing trade volume by trading with each other can be achieved. The trade relations between Iran and India have been assessed from 2001 to 2010.Their findings showed that mineral fuels form larger part of Indian imports from Iran and also India's exports to Iran include inorganic chemicals, articles of iron or steel, drugs and pharmaceuticals. The export's share in Indian has remarkably increased in the span of 1990-2014. India's share of world exports had increased from $0.5 \%$ in 1990 s and crossed $1.7 \%$ by 2014 . The Rice, Spices, 
(Pearls, precious and semi-precious stones) goods were outstanding exports goods. The first ranking of India's share of world exports is pertained to Rice good by $30,4 \%$ in 2014 that it has dominated the top of the rank of Indian's export although its share has been 6,4 \% in 1990. As the Appendix table 3 shows, in 2014 the Spices by $16.3 \%$ share has placed in second position. Its share of export has been confronted with increase and was $7.7 \%$ in 2011. The Third statue of Indian export relates to Pearls, precious and semi-precious stones goods. Its share of export has increased from 9,8 \% in 1990 to $14,7 \%$ in 2014 . The Cereals and cereal preparations goods have had the $8.1 \%$ share of total export of Indian goods in 2014 as well. The most decrese of India's share of world exports is pertained to Tea and mate goods by $7.7 \%$ in 2014 that it had domination the top of the rank of Indian's export in 1990 by $22.1 \%$.

In sum of 45 items of the Indian's prominent exports commodities, about 27 item by $60 \%$ have had RCA index more than one in 2014. This numeric criterion states the comparative advantage of export goods. This index has decreased from of $68 \%$ in 2000 for Indian's exports commodities. According to calculation on the table 4 during 1990-2014, among of India's exports commodity to world, items such as (Tea and mate), (Spices) , (Rice) , (Pearls, precious and semi-precious stones),(Textile yarn, fabrics, made-up articles), (Cereals and cereal preparations), (Leather, Leather manufactures and dressed fur skins), have had the most amount of RCA index .Some of commodity as (Medicinal and pharmaceutical products) and (Vegetables and fruits) (Iron ore and concentrates) has lost the comparative advantage along the years 1990-2014. In contrast, some of commodity as (Iron and steel), (Other transport equipment), (Meat and meat preparations), (Sugar, sugar preparations and honey) have gained the comparative advantage in the Indian's exports basket. Other commodity as (Chemical materials and products n.e.s.), (Machinery specialized for particular industries), (Road vehicles (including air cushion vehicles), (General industrial machinery \& equipment \& machine parts thereof), (Office machinery and ADP equipment), (Telecommunication and sound recording and reproducing apparatus and equipment) and etc., have not had the comparative advantage in comparison to other exports commodity in Indian's exports commodity. To sum up, as the Appendix table 4 reveal, since the 1990s, India has been gaining comparative advantage in a number of products within the groups of Food items, Textiles, Leather and other Manufactures that they are mainly related to agriculture sector. As Shinoj \& Mathur (2008) have shown India had enjoyed a comparative advantage in agriculture exports. By definition, each country has a comparative advantage in some products, depending upon the opportunity cost of producing various products in different sectors. Thus, it seems there is a comparative advantage in a larger number of unskilled labor and low or medium technology-intensive products.

\section{Summery and Conclusion}

This study has analyzed comparative advantages of Indian's exports commodities.The analysis of results show India has strengthened its position in exports of agricultural products.Some goods ,for instance (Tea and mate), (Spices), (Rice ) were able to rank in the top postion of share export in the world but, as far as the exports of industrial manufacturing and capital goods are concerned, India could not improve to have a comparative advantage in the world in comparision with other countries espescially Asian countries such as China in manufacturing products. Our study in respect with other studies found out that India has wellknown advantage in lots of commodities and goods such as food, agricultural items. albeit, it seems the plan and program must be considered toward export specialization such as high value-added knowledge and technology intensive industries instead of labor and natural resource intensive products.

\section{Reference}

Batra, A. \& Zeba, K. (2005). Revealed comparative advantage and analysis for India and China. Indian Council for Research On International Economic Relations.

Balasa, B. (1965). Trade Liberalization and revealed comparative Advantage. The Manchester school of Economic and school social studies, 33, 99-123.

Burange, L. G. (2008). India's Revealed Comparative Advantage in Merchandise Trade. Artha vijñāna: journal of the Gokhale Institute of Politics and Economics, Poona (India), 4, 332-363

Datt, R. \& Sundharam, K. P. M. (2010). Indian Economy, revised sixty first editions, published by S. Chand \& company Ltd.

Economic Survey -census annual (Statistical Appendix) 
Fathipour, G. \& Ghahremanlou, A. (2014). Economical-Regional Integration - An Overview on Iran-India Trade Relation. Elsevier, Procedia - Social and Behavioral Sciences, 157(2).

Lee, G. (1995). Comparative Advantage in Manufacturing as a Determinant of industrialization: The Korean case. World Development, 23(7).

Ministry of Commerce \&Industry, Government of India

Misra, S. K. \& Puri, V. K. (1998). Indian Economy, Sixteen Revised and Enlarged Edition, Himalaya Publishing House

RBI, database on Indian economy, Reserve bank of India, www.rbi.org.in (2012)

Shinoj, P. \& Mathur, V. C. (2008). Comparative Advantage of India in Agricultural Exports vis-á-vis Asia: A Post-Reforms Analysis.

Sinate, D., Fanai, V. \& Chakrabarti, D. (2012). Potential for enhancing Indian's trade with Iran: a brief analysis, Export-Import Bank of India. Working paper no.18

Stiglitz, J. (2002). Globalization and its discontent, W.W. Norton \& Company, USA

Vollrath, T. (1991). A theoretical Evaluation of Alternative Trade Intensity measures of Revealed Comparative Advantage. Weltwirts Chaftliches archive, 127(2), 265-280

Workman, D. (2017). www.Worldtopexports.com

Table 3: India's share in world export by commodity division and groups 1990-2014

\begin{tabular}{lllll}
\hline Commodity & $\mathbf{1 9 9 0}$ & $\mathbf{2 0 0 0}$ & $\mathbf{2 0 1 0}$ & $\mathbf{2 0 1 4}$ \\
\hline Meat and meat preparations & 0.2 & 0.7 & 1.6 & 3.4 \\
Fish, crustaceans and molluscs \& preparations & 1.6 & 2.7 & 2.4 & 4.0 \\
Cereals and cereal preparations & 0.6 & 1.5 & 3.3 & 8.1 \\
Rice & 6.4 & 10.2 & 11.2 & 30.4 \\
Vegetables and fruits & 0.8 & 1.3 & 1.3 & 1.4 \\
Sugar, sugar preparations and honey & 0.1 & 0.9 & 2.4 & 2.8 \\
Coffee, tea, cocoa, spices and manufactures & 4 & 3.4 & 2.8 & 3.0 \\
Coffee and coffee substitutes & 1.7 & 2.3 & 1.9 & 2.1 \\
Tea and mate & 22.1 & 14 & 10 & 7.7 \\
Spices & 7.7 & 10.3 & 15.4 & 16.3 \\
Feeding stuff for animals & 2.2 & 2.3 & 3.6 & 2.4 \\
Tobacco and tobacco manufactures & 0.8 & 0.7 & 2.5 & 2.2 \\
Unmanufactured tobacco and refuse & 2.1 & 2.7 & 6.6 & 5.7 \\
Manufactured tobacco & 0.3 & $\ldots$ & 0.7 & 0.9 \\
Oilseeds and oleaginous fruit & 0.8 & 1.7 & 1.6 & 2.2 \\
Metalliferous ores and metal scrap & 2.1 & 1 & 2.8 & 0.7 \\
Iron ore and concentrates & 7.6 & 3.9 & 5.9 & 0.7 \\
Organic chemicals & 0.3 & 1.1 & 2.3 & 2.8 \\
Inorganic chemicals & 0.2 & 0.3 & 1.1 & 0.9 \\
Dyeing, tanning and colouring materials & 1.2 & 1.4 & 2.4 & 3.8 \\
Medicinal and pharmaceutical products & 1.2 & 1.2 & 1 & 1.2 \\
Essential oils and perfume materials soap, cleansing etc. & 1.1 & 0.5 & 0.9 & 1.2 \\
Artificial resins, plastic materials, cellulose esters \& ethers & $\ldots$ & 0.1 & 0.8 & 0.9 \\
Chemical materials and products n.e.s. & 0.2 & 0.7 & 1.2 & 1.5 \\
Leather, leather manufactures \& dressed fur skins & 6.3 & 3.3 & 3.3 & 4.7 \\
Leather & 4.8 & 2.3 & 3.4 & 5.0 \\
Manufactures of leather or of composition leather & 13.4 & 6.2 & 4.2 & 5.4 \\
Fur skins, tanned or dressed etc. & $\ldots$ & $\ldots$ & 0 & 0.0 \\
Textile yarn, fabrics, made-up articles & 2.1 & 3.6 & 5 & 5.7 \\
Woven cotton fabrics & 3.7 & 4.9 & 3.7 & 5.8 \\
Woven fabrics of manmade fibres & 0.7 & 1.6 & 5.5 & 4.5 \\
Woven fabrics other than of cotton or man-made fibres & 2.3 & 3.9 & 5.2 & 3.0 \\
Pearls, precious and semi-precious stones & 9.8 & 12 & 17.4 & 14.7 \\
Iron and steel & 0.3 & 1 & 2.5 & 2.5 \\
Manufactures of metals n.e.s. & 0.5 & 0.9 & 1.4 & 2.0 \\
Power-generating machinery \& equipment & 0.2 & 0.1 & 0.7 & 1.0 \\
& & & & \\
& &. .3 & &
\end{tabular}


Machinery specialized for particular industries

Metal-working machinery

General industrial machinery \& equipment \& machine parts thereof

Office machinery and ADP equipment

Telecommunication and sound recording and reproducing apparatus and equipment

Electrical machinery, apparatus and appliances

Road vehicles (including air cushion vehicles)

Other transport equipment

Articles of apparel and clothing accessories

Total Exports

source: Economic survey census years (Statistical Appendix) $\begin{array}{llll}0.2 & 0.2 & 0.6 & 1.0\end{array}$

$\begin{array}{llll}0.2 & 0.3 & 0.5 & 0.6\end{array}$

$\begin{array}{llll}0.1 & \ldots & 0.7 & 0.9\end{array}$

$\begin{array}{llll}0.1 & \cdots & 0.1 & 0.1\end{array}$

$\begin{array}{llll}\cdots & \ldots & 0.4 & 0.3\end{array}$

$\begin{array}{llll}0.1 & \cdots & 0.4 & 0.4\end{array}$

$\begin{array}{llll}0.1 & 0.1 & 0.8 & 1.0\end{array}$

$\begin{array}{llll}0 . . & \ldots & 1.7 & 3.0\end{array}$

$\begin{array}{llll}2.3 & 3.5 & 3 & 3.5\end{array}$

$\begin{array}{llll}0.5 & 0.7 & 1.5 & 1.7\end{array}$

Table 4: Comparative advantage index for each of Indian's exports commodity 1990-2014

\begin{tabular}{lllll}
\hline Commodity & $\mathbf{1 9 9 0}$ & $\mathbf{2 0 0 0}$ & $\mathbf{2 0 1 0}$ & $\mathbf{2 0 1 4}$ \\
\hline Meat and meat preparations & 0.41 & 1.09 & 1.10 & 1.96 \\
Fish, crustaceans and molluscs \& preparations & 2.89 & 4.12 & 1.60 & 2.32 \\
Cereals and cereal preparations & 1.15 & 2.20 & 2.25 & 4.75 \\
Rice & 11.58 & 15.36 & 7.58 & 17.77 \\
Vegetables and fruits & 1.45 & 1.89 & 0.88 & 0.83 \\
Sugar, sugar preparations and honey & 0.27 & 1.28 & 1.60 & 1.62 \\
Coffee, tea, cocoa, spices and manufactures & 7.26 & 5.15 & 1.88 & 1.77 \\
Coffee and coffee substitutes & 3.11 & 3.44 & 1.29 & 1.25 \\
Tea and mate & 40.20 & 21.02 & 6.77 & 4.51 \\
Spices & 14.03 & 15.46 & 10.46 & 9.51 \\
Feeding stuff for animals & 3.92 & 3.48 & 2.43 & 1.41 \\
Tobacco and tobacco manufactures & 1.48 & 1.02 & 1.66 & 1.30 \\
Unmanufactured tobacco and refuse & 3.76 & 4.01 & 4.47 & 3.35 \\
Manufactured tobacco & 0.56 & 0.00 & 0.45 & 0.51 \\
Oilseeds and oleaginous fruit & 1.44 & 2.55 & 1.10 & 1.27 \\
Metalliferous ores and metal scrap & 3.84 & 1.55 & 1.92 & 0.40 \\
Iron ore and concentrates & 13.75 & 5.92 & 4.02 & 0.44 \\
Organic chemicals & 0.60 & 1.67 & 1.56 & 1.64 \\
Inorganic chemicals & 0.41 & 0.45 & 0.71 & 0.53 \\
Dyeing, tanning and colouring materials & 2.13 & 2.12 & 1.63 & 2.20 \\
Medicinal and pharmaceutical products & 2.18 & 1.76 & 0.68 & 0.69 \\
Essential oils and perfume materials soap, cleansing & 2.08 & 0.73 & 0.64 & 0.70 \\
etc. & & & & \\
Artificial resins, plastic materials, cellulose esters \& & 0.08 & 0.21 & 0.57 & 0.55 \\
ethers & & & & \\
Chemical materials and products n.e.s. & 0.41 & 1.04 & 0.83 & 0.88 \\
Leather, leather manufactures \& dressed fur skins & 11.45 & 4.98 & 2.20 & 2.73 \\
Leather & 8.76 & 3.53 & 2.27 & 2.90 \\
Manufactures of leather or of composition leather & 24.44 & 9.28 & 2.84 & 3.13 \\
Fur skins, tanned or dressed etc. & 0.00 & 0.00 & 0.00 & 0.00 \\
Textile yarn, fabrics, made-up articles & 3.78 & 5.39 & 3.35 & 3.34 \\
Woven cotton fabrics & 6.68 & 7.42 & 2.50 & 3.38 \\
Woven fabrics of man made fibres & 1.29 & 2.37 & 3.72 & 2.65 \\
Woven fabrics other than of cotton or man-made fibres & 4.19 & 5.91 & 3.54 & 1.75 \\
Pearls, precious and semi-precious stones & 17.89 & 18.02 & 11.79 & 8.59 \\
Iron and steel & 0.48 & 1.53 & 1.72 & 1.44 \\
\hline
\end{tabular}




\begin{tabular}{|c|c|c|c|c|}
\hline Manufactures of metals n.e.s. & 0.94 & 1.40 & 0.94 & 1.16 \\
\hline Power-generating machinery \& equipment & 0.28 & 0.21 & 0.48 & 0.57 \\
\hline Machinery specialized for particular industries & 0.36 & 0.31 & 0.41 & 0.58 \\
\hline Metal-working machinery & 0.34 & 0.43 & 0.37 & 0.33 \\
\hline $\begin{array}{l}\text { General industrial machinery \& equipment \& machine } \\
\text { parts thereof }\end{array}$ & 0.18 & 0.05 & 0.50 & 0.52 \\
\hline Office machinery and ADP equipment & 0.16 & 0.00 & 0.07 & 0.05 \\
\hline $\begin{array}{l}\text { Telecommunication and sound recording and } \\
\text { reproducing apparatus and equipment }\end{array}$ & 0.06 & 0.00 & 0.26 & 0.16 \\
\hline Electrical machinery, apparatus and appliances & 0.24 & 0.02 & 0.30 & 0.24 \\
\hline Road vehicles (including air cushion vehicles) & 0.20 & 0.10 & 0.56 & 0.58 \\
\hline Other transport equipment & 0.03 & 0.05 & 1.18 & 1.78 \\
\hline Articles of apparel and clothing accessories & 4.26 & 5.30 & 2.06 & 2.07 \\
\hline
\end{tabular}

Source: The researchers' calculation 